$\xi=$

\title{
Detection of Porcine Adulteration in Cosmetic Cream Formulation via TaqMan Probe Real-Time Polymerase Chain Reaction.
}

\author{
S S Abd-Gani ${ }^{1,2 *}$, S Mustafa ${ }^{1}$, M N Mohd Desa ${ }^{1}$, N F Khairil Mokhtar ${ }^{1}$, U K Hanapi ${ }^{1}$, Z Zakaria ${ }^{3}$, \\ N Yahaya ${ }^{4}$, W M A Wan Sulaiman ${ }^{5}$ \\ ${ }^{1}$ Halal Products Research Institute, Universiti Putra Malaysia, Putra Infoport, 43400 UPM Serdang, Selangor, Malaysia. \\ ${ }^{2}$ Department of Agriculture Technology, Faculty of Agriculture, Universiti Putra Malaysia, 43400 UPM Serdang, Selangor Malaysia. \\ ${ }^{3}$ University of Malaya Halal Research Centre, University of Malaya, 50603 Kuala Lumpur, Malaysia. \\ ${ }^{4}$ Faculty of Science and Technology, Universiti Sains Islam Malysia, 71800 Nilai, Negeri Sembilan, Malaysia. \\ ${ }^{5}$ Kuliyyah of Pharmacy, International Islamic University Malaysia, 25200 Kuantan, Pahang. \\ *Corresponding author E-mail: ssalwa.abdgani@gmail.com
}

\begin{abstract}
The identification of lard adulterated in cosmetic cream using TaqMan probe real-time Polymerase Chain Reaction was developed in this research. The laboratory prepared cream was formulated with oil in water $(\mathrm{o} / \mathrm{w})$ emulsion with the adulteration of $1 \%, 3 \%$ and $5 \%$ of lard $(\mathrm{w} / \mathrm{w})$. The total DNA from lard-adulterated cosmetic cream was successfully extracted. The detection assay targeting different gene; universal 18S rRNA and porcine-specific multiple porcine repetitive element (MPRE) which employed with the TaqMan probe. This study targeting $187 \mathrm{bp}$ of amplicons for $18 \mathrm{~S}$ rRNA while $99 \mathrm{bp}$ of amplicons for Porcine-specific probes. A comparison of quantification cycle $\left(\mathrm{C}_{\mathrm{q}}\right)$ with prior to percentage of adulteration were detected. Lard-adulterated cream was amplified for 18S rRNA while no detection was detected for Porcine-specific probes. The $\mathrm{Cq}$ value obtained might be vary as proposed by the hypothesis depending on the total recovery of extracted DNA from the lard-adulterated cream.
\end{abstract}

Keywords: Cosmetic cream; MPRE; TaqMan probe; Real-time PCR; $18 S$ rRNA.

\section{Introduction}

The existence of cosmetics has been around for a long time for its notorious function. The main purpose for using cosmetics are to enhance attractiveness, to protect skin and hair and to prevent aging (Mitsui, 1997). Cosmetics products are enjoyed by millions of people all over the world. The cosmetic industry is constantly changing with the introduction of new and distinctive products internationally that has set new trend for many cosmetics manufacturer (Mohd Daud, Abdul Aziz, Baharudin, \& Shamsudin, 2012). As the consequences from the advance in cosmetic innovations, consumers often do not know the source of ingredients and its processing. The identity of ingredients in processed or composite mixtures is not usually readily apparent. Thus, verification of authentication of the sources to the consumer may be required (Lockley \& Bardsley, 2000).

Halal is attaining its attention globally due to awareness in Halal food and Halal product. Muslim consumer especially has broadened their perspective of halal from meat-based to wide range of products. This overview has brought Muslim in seeking Halal integrity not only from food but also in beverages, insurance, leather product, pharmaceutical and even in cosmeceutical field (Hunter, 2012). It is reported that Muslim population is growing tremendously in a total of nearly 2 billion. IrfanSungkar in Halal Journal (May \& June, 2009) reported that Muslim in the world were estimated was 1.73 billion and it will increase by 1.85 billion by 2010 . While in Malaysia itself that have a Muslim population of $60.4 \%$, is mapping its position onto Halal industry in product and services and act as the halal hub centers for the worldwide market (Iberahim, Kamaruddin, \& Shabudin, 2012).

In most countries, lard substituent in cosmetic formulation being commonly used as a viscosity-increasing agent in several cosmetic products (Rohman \& Man, 2011). This substituent is used due to its vast production and cheap cost. However, the consumption of lard in cosmetic is prohibited in certain religion like Islam. Thus, the detection lard in cosmetic products plays the significance role for the benefit of Muslim consumer.

Mostly, a few methods of the detection of porcine in the wide range of processed food have been developed. It is either lipidbased method, protein based-method or DNA-based method. While cosmetics also can be classified as highly process products that underwent harsh process. In recent years, nanotechnology has grown in both pharmaceutical and cosmeceutical. Nanoemulsion is oil in water emulsion that use high-pressure homogenizer to produce nanoemulsion of extremely low particle size $(\mathrm{nm})$ (Sharma \& Sarangdevot, 2012; Yukuyama et al., 2016). This technique is widely used in cosmetic products to provide a better penetration into the skin.

An analytical method in detection of lard in formulated cosmetic lotion has been developed in recent years. This analytical method is using FTIR spectroscopy to determine emulsifying system of virgin coconut oil in cream formulation (Lukitaningsih, Sa'adah, Purwanto, \& Rohman, 2012). However this method have limitation on the lard detection of commercial nanotechnology 
cosmeceutical product. Since FTIR spectroscopy can only be used for certain formulations (Rohman \& Man, 2011), further study needs to be carried out for the detection of porcine in the cosmetic cream.

Polymerase Chain Reaction (PCR) using DNA-based approaches that are well known as specific, reproducible, sensitive, rapid processing time and low cost (Alfie \& Farouk, 2013). Its ability to amplify the targeted sequence assists in detection of interest region of DNA. Plus, PCR is proven to be an adequate for the detection of small amount of DNA in a rapid and sensitive manner (Aida, Man, Wong, Raha, \& Son, 2005). In addition, Real time PCR is another applied PCR methodology that provides speed and real-time detection in results generation as this method using fluorescence detection system. This fluorescence signal is utilized to measure amount of DNA in the sample. The data from the fluorescent detection system can be directly obtained (eliminating electrophoresis step) and allowing the selection for short sequences for amplification (López-Andreo, Lugo, Garrido-Pertierra, Prieto, \& Puyet, 2005).

\section{Materials and method}

\subsection{Samples}

Raw meat samples from the animal species comprising of beef, chicken, fish, goat, sheep, pork and plant species including corn, palm, sesame, soybean, sunflower were purchased at the local supermarket located at Serdang, Selangor. Porcine adipose tissue samples were purchased from the wet market in Seri Kembangan, Selangor. These samples were subjected as a controls in this study.

\subsection{Extraction of lard from pig adipose tissue}

The porcine adipose tissue was cut into small pieces and melted in a conventional oven at $225^{\circ} \mathrm{C}$. The melted lard was filtered using the muslin cloth. Lard was stored in $4^{\circ} \mathrm{C}$ chiller in a closed container.

\subsection{Preparation of laboratory cosmetic cream}

The cosmetic cream was formulated using oil-in-water $(\mathrm{o} / \mathrm{w})$ emulsion in the total amount of $100 \%$ by weight. The formulated cream consisted of jojoba oil $(5.0 \% \mathrm{w} / \mathrm{w})$ and olive oil $(5 \% \mathrm{w} / \mathrm{w})$ as the dispersed oil phase. While for the continuous phase it contained Tween $20(12 \% \mathrm{w} / \mathrm{w})$, xantham gum $(2 \% \mathrm{w} / \mathrm{w})$ and water $(76 \% \mathrm{w} / \mathrm{w})$. They were weighed and transferred separately into a $250 \mathrm{ml}$ beaker and heated to a temperature in the range of $60^{\circ} \mathrm{C}$ $70^{\circ} \mathrm{C}$ with continuous stirring with a magnetic stirrer bar. The oilphase were added dropwise into the water phase with continuous head stirrer at $1000 \mathrm{rpm}$.

\subsection{DNA Extraction}

\subsubsection{Raw samples}

Animal and plant DNA were extracted using Wizard Genomic DNA Purification Kit (Promega) according to manufacturer's protocol. 1ng of template DNA was used in real-time PCR assays.

\subsubsection{Lard-adulterated cosmetic cream sample}

The DNA extraction for the lard-adulterated cosmetic cream sample was carried by using modified CTAB method by Doyle \& Doyle using $300 \mathrm{mg}$ of total sample. This method was based on the CTAB (cetyltrimethylam- monium bromide) $(2 \%(\mathrm{w} / \mathrm{v}) \mathrm{CTAB}$ $3 \mathrm{M} \mathrm{NaCl}$, 20mMEDTA and 100mMTris-HCl (pH 8.0) as lysis buffer and adding chloroform:isoamyl alcohol (24:1) in the lysis phase. $10 \mathrm{M}$ ammonium acetate and cold isopropanol were added into the aqueous phase for DNA precipitation. The extracted DNA sample was eluted in $30 \mu \mathrm{L}$ of Tris-EDTA (TE) buffer. The eluted DNA was kept for further purification step using DNA Clean and Concentrator-ZYMO Research kit as indicated in the manufacturer's protocol.

\subsection{Probe and primer design}

For the endogenous control assay, The Applied Biosystems ${ }^{\circledR}$ Eukaryotic 18S rRNA Endogenous Control (VIC ${ }^{\circledR} /$ MGB Probe, Primer Limited) was purchased from Thermo Fisher Scientific. This VIC® dye-labeled TaqMan ${ }^{\circledR}$ MGB probe consist of two amplification primers (forward and reverse) provided in a preformulated 20X mix; 1X final concentration are $250 \mathrm{nM}$ for the probe and $150 \mathrm{nM}$ each primer.

In the case of porcine-specific primers and probes, Meat Animal Research Centre Porcine Repetitive Element (MPRE) was chosen to design porcine-specific primers and probes. The properties of all primers and probe as being assessed using online oligoDT analyser tool are as in Table 1and Table 2 below.

Table 1: Sequence of the designed primers

\begin{tabular}{|c|c|c|c|}
\hline $\begin{array}{l}\text { Real- } \\
\text { time } \\
\text { PCR }\end{array}$ & $\begin{array}{l}\text { Repeti- } \\
\text { tive }\end{array}$ & \multicolumn{2}{|c|}{ Sequence $5^{\prime}-3^{\prime}$ (bp) } \\
\hline \multirow{3}{*}{$\begin{array}{l}\text { Por- } \\
\text { cine- } \\
\text { specif- } \\
\text { ic }\end{array}$} & \multirow{3}{*}{$\begin{array}{l}\text { MPRE } \\
\text { repeti- } \\
\text { tive } \\
\text { element }\end{array}$} & $\begin{array}{l}\text { For- } \\
\text { ward }\end{array}$ & $\begin{array}{l}\text { GGATTTCCATCCCACAGCC } \\
\text { (19) }\end{array}$ \\
\hline & & $\begin{array}{l}\text { Re- } \\
\text { verse }\end{array}$ & $\begin{array}{l}\text { GAGAACAGATGCTGACTCACAGA } \\
(23)\end{array}$ \\
\hline & & Probe & $\begin{array}{l}\text { /56-JOE/CCC } \\
\text { CCAACCCCCAAACTGTCTCCTCC/3I } \\
\text { ABkFQ/ (26) }\end{array}$ \\
\hline
\end{tabular}

Table 2: Properties of the designed primers

\begin{tabular}{|l|l|l|}
\hline $\begin{array}{l}\text { Amplicon length } \\
(\mathrm{bp})\end{array}$ & GC content $(\%)$ & Melting temperature $\left({ }^{\circ} \mathrm{C}\right)$ \\
\hline \multirow{3}{*}{99} & 57.9 & 56.1 \\
\cline { 2 - 3 } & 47.8 & 56.4 \\
\cline { 2 - 3 } & 65.4 & 66.6 \\
\hline
\end{tabular}

\subsection{Real-time PCR}

The real-time PCR assay was carried out in an Eppendorf Mastercycler ${ }^{\circledR}$ ep-realplex machine (Eppendorf, Hamburg, Germany) with $20 \mu$ reaction mixture consisting of $1 \mathrm{x}$ ssoFast probe supermix (Bio-Rad, Hercules, California, USA), $10 \mu \mathrm{mol}$ of TaqMan probe and $0.0 .1 \mathrm{ng} / \mu \mathrm{L}$ of DNA. Required dilution was performed using sterile deionized water and separate tubes for swinespecific assays. A two-step amplification programme consisted of pre-denaturation at $95{ }^{\circ} \mathrm{C}$ for $2 \mathrm{~min}$, followed by 40 cycles of denaturation at $95{ }^{\circ} \mathrm{C}$ for $15 \mathrm{~s}$, and annealing and extension at $51{ }^{\circ} \mathrm{C}$ for 1 minutes was used to conduct experiments in this study. For the endogenous control, the real-time PCR reactions were run for 40 cycles using universal cycling conditions $\left(95^{\circ} \mathrm{C}\right.$ for ten minutes followed by 40 cycles at $95^{\circ} \mathrm{C}$ for 15 seconds and $60^{\circ} \mathrm{C}$ for one minute). All the samples were run in triplicates.

\section{Results and discussion}

\subsection{Unique features of the Real-time PCR system}

This study employed TaqMan real-time PCR via the use of a pair of primers porcine-specific MPRE repetitive element probe (JOE fluorophores at its 5' end and quencher BHQ-1 at its 3' end). By targeting a short amplicon of $99 \mathrm{bp}$, this offered a few advantages comprising of less degradation, efficient amplification, and better capillary electrophoresis (CE) resolution. (M. Eaqub Ali, Hashim, Mustafa, \& Man, 2012). DNA in cosmetic cream may be degraded post harsh processes involving thermal heating and high pressure 
stirring. By employing the detection short targeted amplicons and and hydrolysis probe, the systems offered a higher sensitivity towards detecting animal contaminants from vigorously processed product.

Meanwhile, the pre-formulated mix of endogenous control of $18 \mathrm{~S}$ rRNA gene was amplifiable on eukaryotic DNA covering both animal and plant cells. The use of endogenous control provides several purposes on the information of the total DNA. This total DNA that can be amplified by PCR act as the potential factors such as the presence of PCR inhibitor. Beside, the use of endogenous control also helps to trace the presence of DNA that may not be amplified by the species-specific detectors (primers and probe) (Md Eaqub Ali et al., 2012).

\subsection{Real-time PCR Specificity evaluation}

The specificity of porcine specific Taqman Real-Time PCR assay was determined against various animal (pig, cattle, chicken, goat, fish and sheep) and plant species (corn, palm, sesame, soybean, and sunflower). There was no amplification being detected in all animals and plants DNA except for porcine DNA which giving the evidence of high specificity of the assay to the species. The porcine-specific amplicons was amplified at $99 \mathrm{bp}$ fragment from porcine DNA (Ct value of $18.33 \pm 0.8$ ).

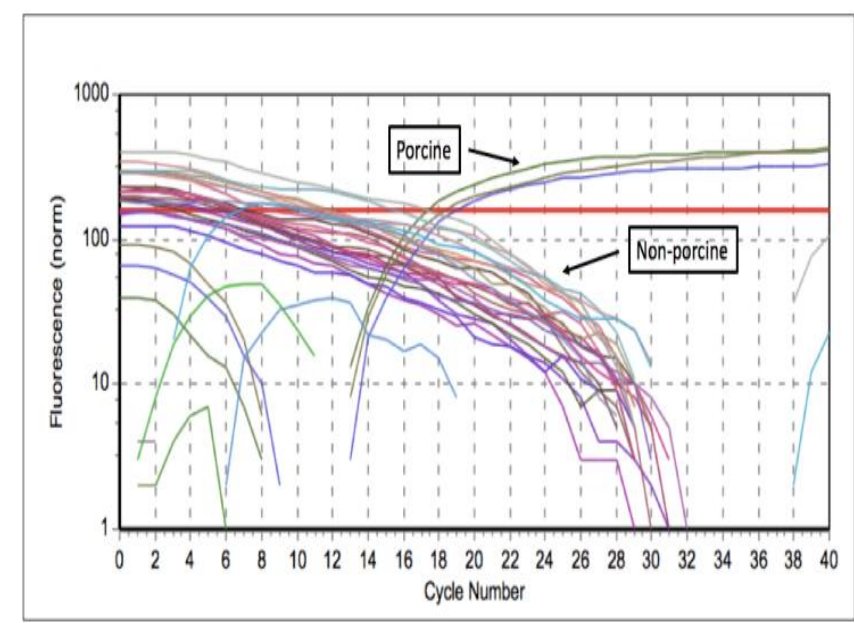

Fig. 1: Specificity test of porcine-specific MPRE

\subsection{Porcine DNA Detection in Cosmetic Cream, PCR Efficiency and Limit of Detection (LOD)}

The detection of lard-adulterated in cosmetic cream sampels was conducted by targeting the endogenous control and porcinespecific MPRE repetitive element. The endogenous control of $18 \mathrm{~S}$ rRNA gene was amplified as amplicons of $187 \mathrm{bp}$. The $18 \mathrm{~S}$ rRNA endogenous control successfully amplified the binary mixture consisting of $1 \%, 3 \%$ and $5 \%(\mathrm{w} / \mathrm{w})$ lard and cosmetic cream. The Ct value of of each binary mixture based on its increment of lard adulteration percentage was detected giving its $\mathrm{Ct}$ value of $35.17 \pm 3.81,36.55 \pm 1.21$ and $38.51 \pm 1.02$ respectively. This $\mathrm{Ct}$ value was higher than its hypothetical value. The hypothesis proposed that, the yield of DNA extracted from lard in the cosmetic cream will proportionally increase by the increment of lard adulteration percentage. Thus, the detection suppose to give the lower $\mathrm{Ct}$ value as the adulteration percentage increase.

This giving arise to the total recovery of lard itself in the cosmetic cream. The rendered lard from the extraction of its oil (melted lard) having the possibility of the absence of its adipose tissue in the melted lard. This inconsistency giving the binary mixture of cosmetic cream and lard an inaccurate total recovery of lardadulteration cream percentage. The residing adipose tissue in the rendered lard may not present in the cosmetic cream as oppose to even up to $5 \%$ of adulteration.

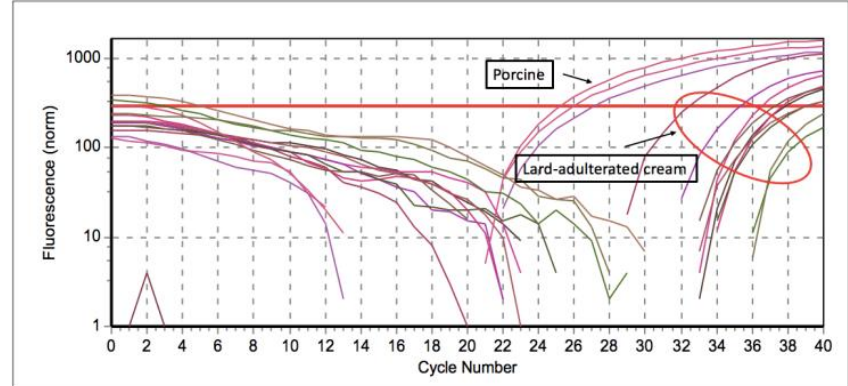

Fig. 2: Lard-adulterated cream detection on endogenous control

The LOD of the porcine-specific TaqMan real-time PCR assay was determined by assaying a tenfold serial dilutions $(0.0001 \mathrm{ng}$, $0.001 \mathrm{ng}, 0.01 \mathrm{ng}, 0.1 \mathrm{ng}$ and $1 \mathrm{ng}$ ) of porcine DNA. The PCR reaction efficiency (E) was calculated using the slope of the standard curve, give the formula of $\mathrm{E}=\left(10^{(-1 / \mathrm{slope})}-1\right)$ (M E Ali et al., 2012). Generally, real-time PCR efficiency vary with high linearity ( $r 2 \geq 0.99$ ) from $E=0.90$ to maximal efficiency values up to $E=1.10$. The theoretical maximum of 1.00 with a slope of -3.320 indicated an optimum PCR efficiency in which the templates doubles exponentially in each cycle (Yusop, Mustafa, Man, Omar, \& Mokhtar, 2012). In this study the the PCR efficiency obtained was $E=1.01$ providing the slope of -3.289 , while the correlation coefficient obtained from the standard curve was $\mathrm{r}^{2}=0.98016$. This indicated that this limit of detection real-time PCR assay fell within in its range of efficiency. However, with prior to the lard adipose tissue total recovery, the lard-adulterated cosmetic cream detection did not reflect the PCR efficiency and limit of detection on porcinespecific MPRE repetitive element. As to this consequences, the presence of porcine in lard-adulterated cream can not be detected.

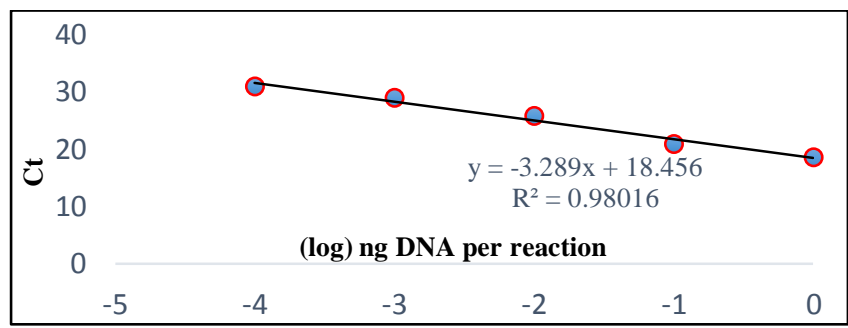

Fig. 3: Standard curve of pork serial dilutions $(1,0.1,0.01,0.001$ and $0.0001 \mathrm{ng})$

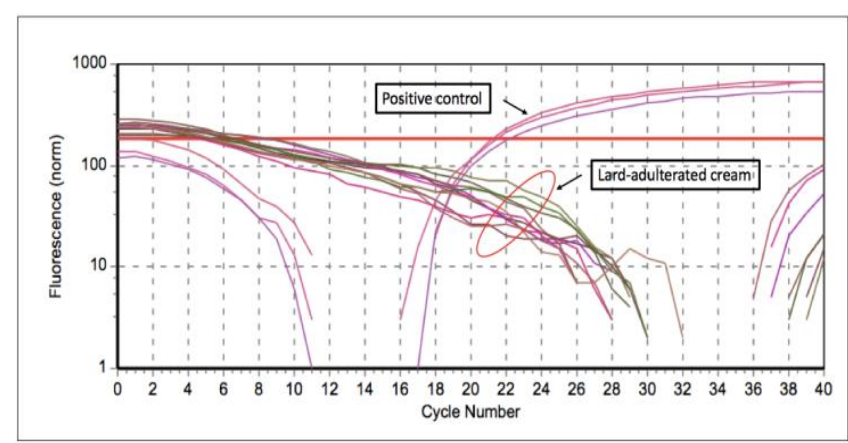

Fig. 4: Detection of lard-adulterated cream on porcine-specific MPRE.

\section{Conclusion}

The detection of porcine DNA in lard-adulterated cream targeting porcine-specific MPRE TaqMan probe real-time PCR was unsuccessfully amplified at $99 \mathrm{bp}$. However, the lard-adulterated cream was amplifiable on 18S rRNA endogenous control showing there was a trace amount of DNA from the extracted cream. This study showed that, formulated cream having a potential that genomic DNA can be extracted from it. 


\section{Acknowledgement}

Suhana mustafa is a beneficiary of Graduate Research Fellowship (GRF) from Universiti Putra Malaysia (UPM). This project was supported by the Ministry of Education Malaysia research grant (grant vote MOO02-2018 awarded to Malaysian Higher Education Consortium of Halal Institutions).

\section{References}

[1] Aida, A. A., Man, Y. B. C., Wong, C. M. V. L., Raha, A. R., \& Son, R. (2005). Analysis of raw meats and fats of pigs using polymerase chain reaction for Halal authentication. Meat Science, 69(1), 47-52. https://doi.org/10.1016/j.meatsci.2004.06.020

[2] Alfie, A., \& Farouk, M. (2013). Short Communication DNA extraction from ghee and beef species identification using polymerase chain reaction ( PCR ) assay, 20(December 2012), 2959-2961.

[3] Ali, M. E., Hashim, U., Mustafa, S., \& Man, Y. B. C. (2012). Swine-Specific PCR-RFLP Assay Targeting Mitochondrial Cytochrome B Gene for Semiquantitative Detection of Pork in Commercial Meat Products. Food Analytical Methods, 5(3), 613623. https://doi.org/10.1007/s12161-011-9290-5

[4] Ali, M. E., Hashim, U., Mustafa, S., Man, Y. B. C., Dhahi, T. S., Kashif, M., ... Hamid, S. B. A. (2012). Analysis of pork adulteration in commercial meatballs targeting porcine-speci fic mitochondrial cytochrome $b$ gene by TaqMan probe real-time polymerase chain reaction. Mesc, 91(4), 454-459. https://doi.org/10.1016/j.meatsci.2012.02.031

[5] Ali, M. E., Hashim, U., Mustafa, S., Man, Y. B. C., Latif, M. A., Islam, K. N., .. Rahman, M. M. (2012). Taqman real-time polymerase chain reaction for the determination of pork adulteration in meat nuggets. Journal of Food and Nutrition Research, 51(1), 1-12.

[6] Hunter, M. (2012). The emerging Halal cosmetic and personal care market March 2012 P E R S O N A L C A R E, 37-41.

[7] Iberahim, H., Kamaruddin, R., \& Shabudin, A. (2012). Hala development system: The institutional framework, issues and challenges for halal logistics. ISBEIA 2012 - IEEE Symposium on Business, Engineering and Industrial Applications, (Mlc), 760-765. https://doi.org/10.1109/ISBEIA.2012.6422993

[8] Lockley, A. K., \& Bardsley, R. G. (2000). DNA-based methods for food authentication. Trends in Food Science and Technology, 11(2), 67-77. https://doi.org/10.1016/S0924-2244(00)00049-2

[9] López-Andreo, M., Lugo, L., Garrido-Pertierra, A., Prieto, M. I., \& Puyet, A. (2005). Identification and quantitation of species in complex DNA mixtures by real-time polymerase chain reaction. Analytical Biochemistry, 339(1), 73-82. https://doi.org/10.1016/j.ab.2004.11.045

[10] Lukitaningsih, E., Sa'adah, M., Purwanto, \& Rohman, A. (2012). Quantitative analysis of lard in cosmetic lotion formulation using FTIR spectroscopy and partial least square calibration. JAOCS, Journal of the American Oil Chemists' Society, 89(8), 1537-1543. https://doi.org/10.1007/s11746-012-2052-8

[11] Mitsui, T. (1997). New Cosmetic Science. Journal of Chemical Information and Modeling, 53(9), 1689-1699. https://doi.org/10.1017/CBO9781107415324.004

[12] Mohd Daud, N., Abdul Aziz, H., Baharudin, N. H., \& Shamsudin, S. F. (2012). Identifying the Determinant Attributes of Halal Cosmetics Product That Influence Its. Journal of Applied Sciences Research, 8(1), 301-313.

[13] Rohman, A., \& Man, Y. B. C. (2011). Analysis of Lard in Cream Cosmetics Formulations Using FT-IR Spectroscopy and Chemometrics, 7(5), 726-732.

[14] Sharma, S., \& Sarangdevot, K. (2012). Nanoemulsions For Cosmetics. International Journal of Advanced Research in Pharmaceutical \& Bio Sciences, 2(3), 408-415.

[15] Yukuyama, M. N., Ghisleni, D. D. M., Pinto, T. J. A., \& BouChacra, N. A. (2016). Nanoemulsion: Process selection and application in cosmetics - A review. International Journal of Cosmetic Science, 38(1), 13-24. https://doi.org/10.1111/ics.12260

[16] Yusop, M. H. M., Mustafa, S., Man, Y. B. C., Omar, A. R., \& Mokhtar, N. F. K. (2012). Detection of Raw Pork Targeting Porcine-Specific Mitochondrial Cytochrome B Gene by Molecular Beacon Probe Real-Time Polymerase Chain Reaction. Food Analytical Methods, 5(3), 422-429. https://doi.org/10.1007/s12161- 